ISSN 2078-6441. Вісник Львівського університету. Серія географічна. 2013. Випуск 44. С. 114-121. Visnyk of the Lviv University. Series Geography. 2013. Issue 44. P. 114-121.

$631.61(477.75)$

\author{
лен ргін \\ врійський н ціон льний університет ім. . . ерн дського, \\ просп. к демік ерн дського, 4, 95007, м. імферополь, кр їн, \\ e-mail:YazcivLena@rambler.ru
}

озр хов но т про н лізов но геохімічні пок зники, які можн використ ти для вивчення генези й еволюції грунтів. осліджено особливості зміни коефіцієнт елювіюв ння, геохімічних коефіцієнтів CIW т CIA, коефіцієнтів з соленості різновікових грунтів у ч сі, які сформув лись у суч сних умов х грунтоутворення н території ер клійського півостров .

лючові слов : геохімічні коефіцієнти, різновікові грунти, літохімічні індекси, коефіцієнти звітрюв ння.

вивченні генези й еволюції грунтів в жливе зн чення м є комплексне використ ння грунтових, т кож геологічних і геохімічних методів досліджень. і методи д ють змогу виявити в грунтовій товщі еволюційні 3 кономірності формув ння пї скл ду т вл стивостей з лежно від геологічних і біоклім тичних ф з розвитку території, протягом яких змінюв вся н прям грунтоутворення. ст ннім ч сом під ч с п леогеогр фічних реконструкцій природного середовищ, геохімічного н лізу суч сних і минулих умов грунтоутворення т звітрюв ння, ідентифік ції вл стивостей грунтів, усп дков них від попередніх ет пів еволюційного розвитку, поч ли з стосовув ти різні геохімічні коефіцієнти - відношення м кро- і мікроелементів [2].

ослідження, доповнені різними петрофізичними і мінер логічними д ними, д ють змогу виявляти зміни у вл стивостях різних відкл день, головно для похов них грунтів. и ж з стосовуємо цей досить рідкісний, одн к перспективний підхід дослідження процесів розвитку й еволюції грунтів для різновікових педосистем римського півостров, що сформув лися н денній поверхні 3 умов суч сної комбін ції чинників грунтоутворення.

руднощі з визн ченням віку грунтів і з г льн нест ч добре д тов них об'єктів $€$ основними обмеженнями в хронологічних дослідженнях [3]. ому проблем ми вивчення геохімічних змін грунтів у ч сі сьогодні з йм ється дуже м ло вчених, перев жно з кордоном. прикл д, . еннеді т ін. [10], . едвік т ін. [7], . урц т ін. [11], н- інь ж н [9] систем тично вивч ли розвиток грунтів н

в йських остров х і н території ит ю і н очно проілюструв ли хімічні й геохімічні зміни грунтів хронорядів. ослідження геохімічних коефіцієнтів д ють змогу визн ч ти вік грунту т швидкість формув ння окремих його пок зників. окрем, у пр ці японських учених з пропонов но новий метод оцінки темпів звітрюв ння і грунтоутворення н підст ві геохімічних моделей порід, грунтів і річкових вод н глоб льному і регіон льному м сшт б х. и побудув ли модель грунтоутворення з використ нням

(C) ргін ., 2013 
середнього вмісту семи основних елементів (Al, Fe, Ca, K, $\mathrm{Mg}$, $\mathrm{Na}$ i $\mathrm{Si}$ ) у земній корі, грунт х і вод х річки, відповідно [14].

сновними геохімічними пок зник ми, які використовують для реконструкцій умов грунтоутворення т звітрюв ння, $\epsilon$ :

літохімічні індекси.

- $\mathrm{CIA}=100 \times \mathrm{Al}_{2} \mathrm{O}_{3} /\left(\mathrm{Al}_{2} \mathrm{O}_{3}+\mathrm{CaO}+\mathrm{Na}_{2} \mathrm{O}+\mathrm{K}_{2} \mathrm{O}\right)-\mathrm{x}$ р ктеризує ступінь звітрюв ння грунтів і порід т їхні мінер логічні особливості [2];

- $\mathrm{CIW}=\left(\mathrm{Fe}_{2} \mathrm{O}_{3}+\mathrm{CaO}+\mathrm{MgO}+\mathrm{Na}_{2} \mathrm{O}+\mathrm{K}_{2} \mathrm{O}+\mathrm{TiO}_{2}\right) / \mathrm{Al}_{2} \mathrm{O}_{3}-$ відобр же ступінь зрілості тонкої люмосілікокл стики [2];

коефіцієнти звітрюв ння:

- $\mathrm{Al}_{2} \mathrm{O}_{3} /\left(\mathrm{CaO}+\mathrm{Na}_{2} \mathrm{O}+\mathrm{K}_{2} \mathrm{O}+\mathrm{MgO}\right)$ - відношення $1_{2}$ (глинист скл дов ) до основних к тіонів, шо виносяться в грунтові розчини [12];

- $\mathrm{Rb} / \mathrm{Sr}$ - $з$ пропонов но н підст ві різниці в стійкості різних мінер лів до звітрюв ння, с ме - слюд і к лієвих польових шп тів, з якими в соці ції перебув $є \mathrm{Rb}$ і к рбон тів, з якими соціює $\mathrm{Sr}[4,13]$;

- $\left(\mathrm{Fe}_{2} \mathrm{O}_{3}+\mathrm{MnO}\right) / \mathrm{Al}_{2} \mathrm{O}_{3}-\mathrm{x}$ р ктеризує ступінь окислення грунтового м тері лу [2];

- $\mathrm{Na}_{2} \mathrm{O} / \mathrm{K}_{2} \mathrm{O},\left(\mathrm{K}_{2} \mathrm{O}+\mathrm{Na}_{2} \mathrm{O}\right) / \mathrm{Al}_{2} \mathrm{O}_{3}, \mathrm{Na}_{2} \mathrm{O} / \mathrm{Al}_{2} \mathrm{O} 3$ - х р ктеризує поведінку легкорозчинних солей у профілі грунту [4];

- $\quad \mathrm{iO}_{2} / 1_{2}$ з - д є змогу оцінити ступінь однорідності м тері лу $[2,13]$.

кту льність проблеми т відсутність н логічних досліджень в кр їні зумовили н шу мету - дослідити поведінку геохімічних коефіцієнтів у ч сі н прикл ді різновікових грунтів, що формуються в суч сних умов х грунтоутворення н території ер клійського півостров риму.

ході вивчення особливостей грунтоутворення в меж $\mathrm{x}$ ередгірського риму ми дослідили різновікові грунти, що сформув лись н території ер клійського півостров н : н сипі ртилерійської б т реї, руїн х фортеці емб ло, з лишк х стін ерсонес т н території клерів (д вніх сільськогоспод рських н ділів) тр бонового ерсонес , шо був н території ячного півостров .

йбільше поширені н ер клійському півострові куестово-шиблякові місцевості з коричневими грунт ми. ур хув нням суч сних уточнень л ндш фтн структур визн чен структурно-денуд ційним передгір'ям н неогенових в пняк х і мергелях 3 коричневими гірськими щебенюв тими грунт ми під колючими ч г рниковими 3 ростями, ялівцевими ліс ми т фриг ноїдно-різнотр вними степ ми $[1,6]$. лім т p йону дуже посушливий, помірно ж ркий з дуже м'якою зимою, для нього х р ктерн сум тмосферних оп дів 350-475 мм у рік, середня річн темпер тур 10,3-12,0 ${ }^{\circ}$.

умов х горбисто-б лочного куестового рельєфу (н висот х до 400 м н д рівнем моря) дубово-ялівцеві, дубово-фіст шкові рідколісся і шибляк (гр бинник, держидерево, глід т інші ксерофітні види) х р ктеризують 3 хідний передгірний в рі нт субсередземноморського л ндш фту [1].

г льний вміст елементів у грунті досліджено з методикою вимірюв нь м сової ч стки мет лів і їхніх оксидів у порошкових зр зК х грунтів методом рентгенфлуоресцентного н лізу н прил ді “ пектроск н-м кс-gv”. изн чено м сові ч стки 18 м кро- і мікроелементів для грунтів і грунтотворних порід ер клійського півостров . основі д них в лового вмісту м кро- і мікроелементів у досліджув них грунт х ми обчислили зн чення літохімічних індексів. ні розр хунків геохімічних коефіцієнтів н ведено в т блиці. 
еохімічні пок зники різновікових грунтів

\begin{tabular}{|c|c|c|c|c|c|c|c|c|c|c|c|c|}
\hline б'єКт, грунти & 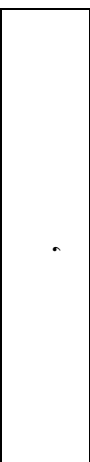 & 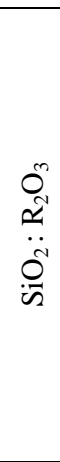 & 0 & $\Xi$ & 光 & 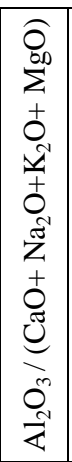 & $\frac{\dot{n}}{\frac{2}{2}}$ & 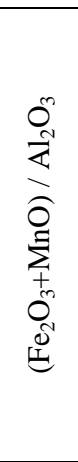 & 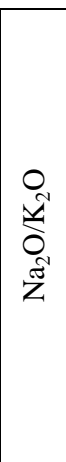 & 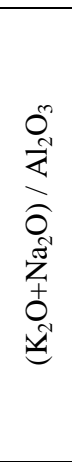 & 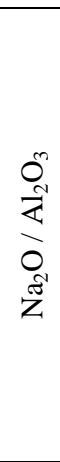 & $\frac{0.0}{n}$ \\
\hline $\begin{array}{l}\text { лишки } \\
\text { ртилерійської } 6 \text { т реї }\end{array}$ & 100 & 2,54 & 0,60 & 17,19 & 60,08 & 0,21 & 0,15 & 3,15 & 2,36 & 2,42 & 0,49 & 0,04 \\
\hline ортеця емб ло & 500 & 3,22 & 2,76 & 41,53 & 21,58 & 0,71 & 0,69 & 5,59 & 0,75 & 2,68 & 0,15 & 0,05 \\
\hline ерсонес врійський” & 1000 & 2,84 & 0,94 & 22,06 & 45,63 & 0,28 & 0,27 & 3,87 & 1,40 & 2,68 & 0,32 & 0,05 \\
\hline $\begin{array}{l}\text { оричневий, } \\
\text { ep клійський п-в }\end{array}$ & 10000 & 2,84 & 3,93 & 51,53 & 17,02 & 1,04 & 0,67 & 7,65 & 1,77 & 2,53 & 0,28 & 0,06 \\
\hline $\begin{array}{l}\text { рунтотворн пород } \\
\text { ер клійський п-в }\end{array}$ & 0 & 2,61 & 1,67 & 35,13 & 26,30 & 0,54 & 1,00 & 5,50 & 1,41 & 1,92 & 0,18 & 0,05 \\
\hline оричневі, мис йя & 10000 & 2,67 & 4,60 & 60,29 & 12,05 & 1,51 & 0,44 & 6,23 & 0,81 & 3,04 & 0,14 & 0,05 \\
\hline рунти клерів & 2000 & 2,28 & 0,87 & 25,29 & 37,83 & 0,34 & 0,40 & 4,00 & 2,59 & 2,07 & 0,35 & 0,04 \\
\hline рунти клерів & 2000 & 3,21 & 2,58 & 39,83 & 22,66 & 0,66 & 0,78 & 5,49 & 1,98 & 1,72 & 0,23 & 0,06 \\
\hline рунтотворн пород & 0 & 2,62 & 0,72 & 19,34 & 52,35 & 0,24 & 0,29 & 3,38 & 3,16 & 2,07 & 0,49 & 0,04 \\
\hline рунти клерів & 2000 & 2,35 & 0,98 & 27,00 & 36,02 & 0,37 & 0,41 & 4,45 & 2,22 & 1,48 & 0,22 & 0,05 \\
\hline рунтотворн пород & 0 & 3,00 & 0,77 & 18,16 & 57,39 & 0,22 & 0,26 & 3,33 & 2,13 & 2,50 & 0,47 & 0,05 \\
\hline рунти клерів & 2000 & 2,72 & 0,99 & 23,64 & 41,80 & 0,31 & 0,17 & 4,19 & 1,94 & 2,36 & 0,35 & 0,05 \\
\hline рунти клерів & 2000 & 2,95 & 2,10 & 36,44 & 25,77 & 0,57 & 0,32 & 5,87 & 1,27 & 2,07 & 0,19 & 0,05 \\
\hline рунти клерів & 2000 & 3,11 & 5,99 & 60,52 & 13,88 & 1,51 & 1,00 & 7,48 & 1,25 & 1,88 & 0,16 & 0,06 \\
\hline оричневі рілля & 10000 & 2,96 & 5,42 & 59,95 & 13,13 & 1,47 & 0,71 & 7,01 & 0,76 & 2,89 & 0,14 & 0,05 \\
\hline лин , м. ерсонес & 0 & 1,53 & 10,57 & 87,61 & 7,17 & 6,95 & 2,29 & 11,95 & 0,18 & 2,26 & 0,02 & 0,03 \\
\hline
\end{tabular}

кож ми розр хув ли молярні відношення кремнезему до полуторних оксидів $\left(\mathrm{SiO}_{2}: \mathrm{R}_{2} \mathrm{O}_{3}\right)$ і коефіцієнт елювіюв ння ( е) (без ур хув ння н трію) в грунт х $\mathrm{i}$ грунтотворних пород $\mathrm{x}$, який 3 пропонов но визн ч ти 3 формулою $\mathrm{e}=\mathrm{SiO}_{2}:\left(\mathrm{RO}+\mathrm{R}_{2} \mathrm{O}\right)$ [5]. ля грунтів досліджув ного регіону т ке розширення випр вд не, оскільки д є змогу ді гностув ти н копичення не тільки мінер лів оксидів 3 ліз й люмінію в тонкодисперсних гр нулометричних фр кціях, й мінер лів-солей, які, зокрем , н дходять ун слідок ер ції з кв торії орного моря.

скільки в хроноряд х з віком зрост є вміст иліцію, то цілком з кономірно, що коефіцієнт елювіюв ння з віком т кож збільшується від 0,6 до 3,93-5,42. ля грунтів хроноряду трив лістю 0-10000 років з фіксов но лінійну з лежність е в ч сі (див. рис. 1). одель м є високі ст тистичні х р ктеристики: коефіцієнт кореляційного відношення дорівнює 0,88 , коефіцієнт достовірності проксим ції - 0,77. 


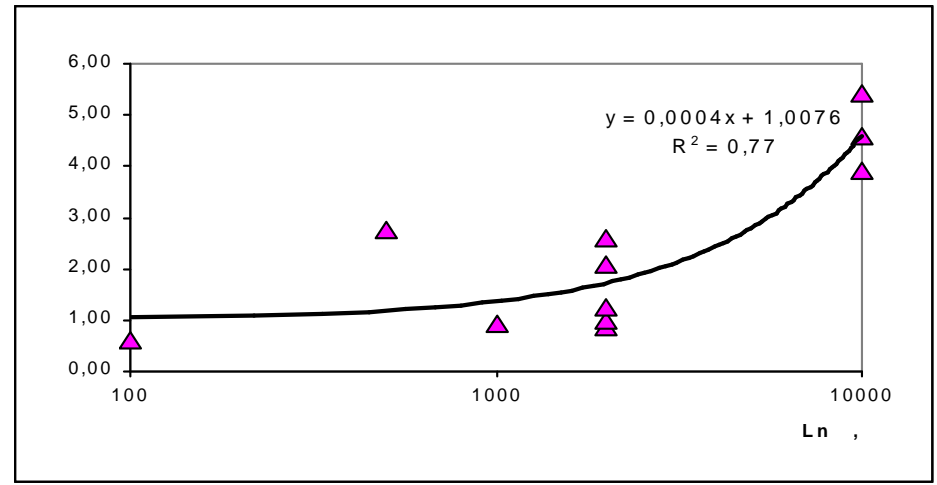

ис. 1. міни коефіцієнт е різновікових грунтів римського півостров впродовж голоцену.

озр хунок молярного відношення $\mathrm{SiO}_{2}: \mathrm{R}_{2} \mathrm{O}_{3}$ д є змогу оцінити втр ту зв'яз ного кремнезему (десилік цію) і н копичення оксидів люмінію і з ліз . і збільшенням вмісту иліцію з віком збільшується т кож вміст полуторних оксидів, причому дуже стрімкими темп ми, тому й відношення $\mathrm{SiO}_{2}: \mathrm{R}_{2} \mathrm{O}_{3}$ змінюється від 2,54 до 3,11 i ст білізується н рівні 2,67-2,96 у повнопрофільних грунт х. ля різновікових грунтів римського півостров ми не виявили чіткої з лежності зміни відношення $\mathrm{SiO}_{2} / \mathrm{R}_{2} \mathrm{O}_{3}$ в ч сі, н відміну від з кономірностей зміни коефіцієнт елювіюв ння - е.

исловлені припущення про особливості генези грунтів, н копичення і тр нсформ ції вихідного м тері лу в процесі грунтоутворення підтверджені змін ми зн чень літохімічного індексу IA, оскільки він відповід $є$ різному ступеню збереження слідів д внього грунтоутворення і звітрюв ння. незвітрілих пород х зн чення , з звич й, низькі, в сильно звітрілих досяг ють 100 [2].

різновікових грунт х коефіцієнт природно м ркув тиме інтенсивність процесів грунтоутворення, тому логічно припустити, що зі збільшенням віку грунту цей коефіцієнт збільшув тиметься. прикл д, у грунт х 100-річного віку зн чення дорівнює 17,2; з віком воно збільшується - у 500-літніх грунт х досяг є 41,53, в грунт х 2000-річного віку - 60,52 (дуже близько до зн чень зон льних грунтів 59,95), що свідчить про сл бкий прояв у них процесів грунтоутворення і звітрюв ння. н логічно в досліджув них грунт х змінюється і літохімічний індекс CIW, який для зручності візу льного відобр ження і форм лізов ного вир ження розр ховув ли в вторській ред кції:

$$
\mathrm{CIW}=\left(\left(\mathrm{Fe}_{2} \mathrm{O}_{3}+\mathrm{CaO}+\mathrm{MgO}+\mathrm{Na}_{2} \mathrm{O}+\mathrm{K}_{2} \mathrm{O}+\mathrm{TiO}_{2}\right) / \mathrm{Al}_{2} \mathrm{O}_{3}\right) \times 10
$$

меншення його зн чень $є$ озн кою збільшення ступеня зрілості тонкої люмосилікокл стики, кількості вл сне глинистих мінер лів порівняно з грунтотворними пород ми, у яких висок ч стк неглинистих силік тних сполук, що м ють CIW пон д 10 [2].

н шому вип дку зн чення CIW грунтотворних порід змінюється від 7,2 до 26,3, у грунт х 100-річного віку його зн чення збільшується до 60,1; у тисячолітніх грунт х - до 45,6, у віці 2000 років - у ді п зоні від 37,1 до 15,43, у зон льних н лог х $13,1-17,0$. 
ндекси CIW i ілюструють відносні втр ти к льцію, к лію і н трію. дослідженні [8] з зн чено, що коефіцієнти і CIW досягли ст більного зн чення н

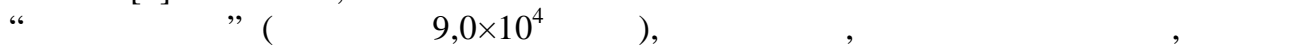
н трію вн слідок грунтоутворення у вологому тропічному клім ті може відбутися дуже швидко. роте втори н голосили, що не виявили з лежності зміни і CIW 3 ч сом (упродовж десяти мільйонів років), отже, ні, ні CIW не можуть бути пок зником розвитку грунту з ч сом. дн к індекси т CIW більше підходять для вивчення р нніх ст дій звітрюв ння гірських порід, не для добре розвинених тропічних грунтів [8].

ід ч с розгляду поведінки розр хов них коефіцієнтів $\quad$ т $\quad$ в в ч сі (н порівняно р нніх ст діях формув ння грунту - протягом голоцену) ми виявили лог рифмічні з лежності цього процесу. р фічну інтерпрет цію зміни в ч сі н зв них вище коефіцієнтів пок $з$ но н рис. 2.

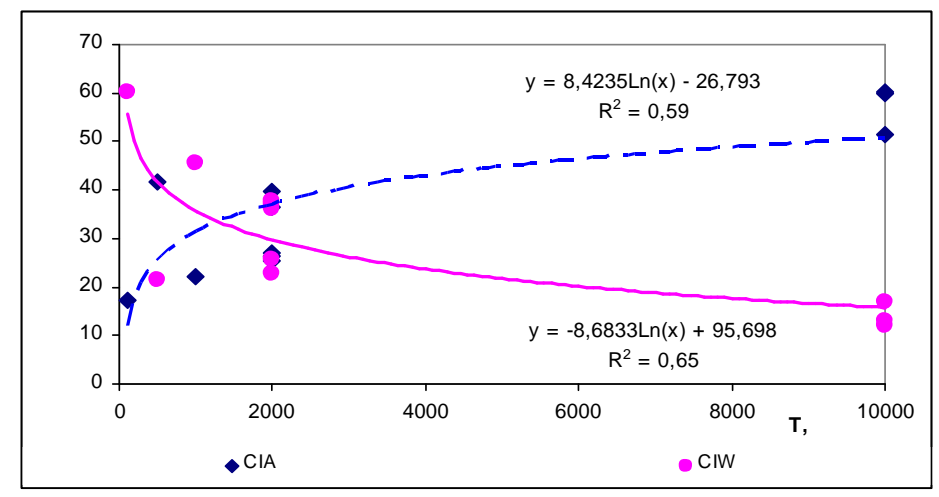

ис. 2. міни коефіцієнтів звітрюв ння (CIW т CIA) різновікових грунтів протягом голоцену.

ході дослідження отрим них м тем тичних моделей виявили, що н йтісніший зв'язок між х р ктеристик ми моделі простежується з умов вр хув ння зн чень коефіцієнтів для зон льних повноголоценових грунтів, що пояснює спрямов ність, цілісність і безперервність процесу грунтоутворення в голоцені т досить трив лі “х р ктерні ч си" процесу. к б чимо з рис. 2, процеси звітрюв ння н поч ткових ет п х грунтоутворення з кономірно інтенсифікуються, потім - після 2 000-2 500 років ст білізуються. ому ми н голошуємо н можливості використ ння для х р ктеристики процесів звітрюв ння т грунтоутворення протягом голоцену індексів т CIW.

оефіцієнт звітрюв ння $\mathrm{Al}_{2} \mathrm{O}_{3} /\left(\mathrm{CaO}+\mathrm{Na}_{2} \mathrm{O}+\mathrm{K}_{2} \mathrm{O}+\mathrm{MgO}\right)$ поряд із іншими геохімічними індекс ми свідчить про посилення процесів звітрюв ння з віком грунту. прикл д, у 100-літніх грунт х його зн чення дорівнює 0,21 , у грунт х клерів $-0,66$, в зон льних грунт $\mathrm{x}-$ пон д 1 .

ідношення $\mathrm{Rb} / \mathrm{Sr}$ i $(\mathrm{Fe} 2 \mathrm{O} 3+\mathrm{MnO}) / \mathrm{Al}_{2} \mathrm{O}_{3}$ т $\quad \mathrm{Al}_{2} \mathrm{O}_{3} / \mathrm{CaO}+\mathrm{NaO}+\mathrm{K}_{2} \mathrm{O}+\mathrm{MgO}$ т кож свідч ть, що м ксим льно процеси звітрюв ння в грунт х виявляються через 2000 років після поч тку грунтоутворення і потім з кономірно зменшуються. проксим ція моделі зміни в ч сі розр хов них коефіцієнтів звітрюв ння з свідчил, що процес т кож м є лог рифмічну природу (див. рис. 3). 

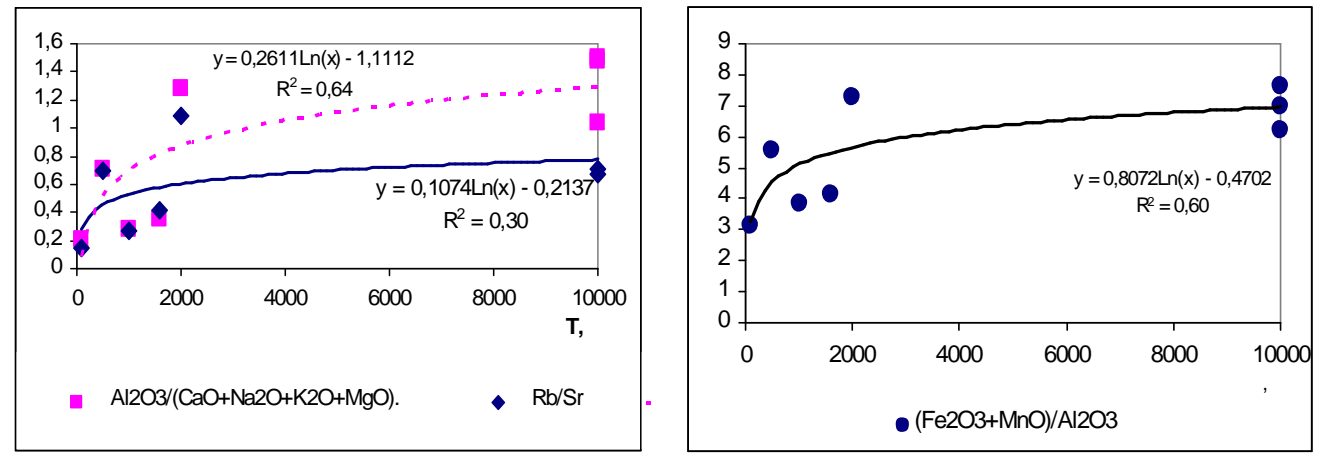

ис. 3. міни коефіцієнтів звітрюв ння в різновікових грунт х.

процесі гідролітичного звітрюв ння відбув ється руйнув ння легкорозчинних мінер лів ун слідок ре кцій гідролізу і под льшого винесення , $\mathrm{Na}_{2} \mathrm{O}, \mathrm{K}_{2} \mathrm{O}, \mathrm{MgO}$, які є основними к тіон ми, що виносяться в грунтові розчини. досліджув них хроноряд х простежується тенденція ст біліз ції бо зниження вмісту легкорозчинних оксидів порівняно ст більних елементів, у н шому вип дку $\mathrm{Al}_{2} \mathrm{O}_{3}$. міни в ч сі коефіцієнтів, що х р ктеризують процеси з солення в грунт х, відобр жено н рис. 4.

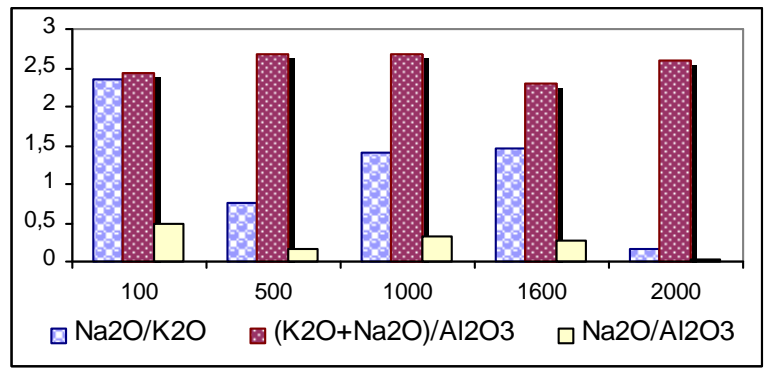

ис. 4. мін в ч сі коефіцієнтів з солення грунту.

оефіцієнт $\mathrm{TiO}_{2} / \mathrm{Al}_{2} \mathrm{O}_{3}$ д є змогу оцінити однорідність грунтотворних порід і визн чити н явність привнесення вторинного м тері лу. ні т блиці свідч ть, що грунти здебільшого є ідентичними (і літологічно однорідними), т підтверджують, що грунти клерів сформов ні н єдиній м теринській породі.

тже, геохімічні коефіцієнти підтверджують суттєву зміну геохімічної обст новки території вн слідок процесів грунтоутворення. еохімічні пок зники х р ктеризують інтенсивність прояву грунтотворного процесу. ослідженнями підтверджено, що 3 ч сом у грунт х інтенсифікуються процеси звітрюв ння, які з г с ють після досягнення грунтом ст ну кв зірівнов ги 3 н вколишнім середовищем. ля х р ктеристики процесів звітрюв ння і грунтоутворення протягом голоцену перспективним $є$ використ ння індексів т CIW. ивчення поведінки геохімічних коефіцієнтів у ч сі д ють змогу визн ч ти вік грунту і швидкість формув ння окремих його вл стивостей 3 використ нням м тем тичних моделей. 


\section{СПИСОК ВИКОРИСТАНОЇ ЛІТЕРАТУРИ}

1. гров . . рымское субсредиземноморье / . . гров , . . оков, . . ркуш , . . р г н // косистемы рым, их оптимиз ция и охр н [тем тич. сб. н учн. тр.]. - имферополь, 2003. - . 95-105.

2. лиз ров . . овременные и реликтовые свойств лесостепных л ндш фтов п дной ибири / . . лиз ров , . . итц, . . ысо [и др.] // ибир. экол. журн. - 2005. - № 5. - . 871-887.

3. ргін . . рунтово-хронологічні дослідження в риму / . . ргін // ізичн геогр фія т геоморфологія. - 2005. - ип. 49. - . 206-212.

4. линин . . еохимические х р ктеристики погребенных голоценовых почв степей риволжской возвышенности / . . линин, . . лексеев // естник . ер. геогр фия, геоэкология. - 2008. - № 1. - . 9-15.

5. ирильчук. . імія грунтів. снови теорії і пр ктикум : н вч. посібник / . . ирильчук, . . онішко. - ьвів : імені в н р нк, 2011.-354 с.

6. овременные л ндш фты рым и сопредельных территорий : моногр фия // [н уч. ред. . . оз ченюк]. - имферополь : изнес- нформ, 2009. - 672 с.

7. Chadwick $O$. A. Changing sources of nutrients during four million years of ecosystem development / O. A. Chadwick, L. A. Derry, P. M. Vitousek [et al.] // Nature. - 1999. Vol. 397. - P. 491-497.

8. Gallet $S$. Geochemical characterization of the Luochuan loess-paleosol sequence, China, and paleoclimaticimplications / S. Gallet, J. Borming, T. Masayuki // Chemical Geology. - 1996. - Vol. 133. - P. 67-88.

9. Gan-Lin Zhang. Geochemical features of a soil chronosequence developed on basalt in Hainan Island, China // Gan-Lin Zhang, Ji-Hua Pan, Cheng-Min Huang, Zi-Tong Gong // Revista Mexicana de Ciencias Geológicas. - 2007. - Vol. 24. - N 2. - P. 261-269.

10. Kennedy M.J. Changing sources of base cations during ecosystem development, Hawaiian Islands / M. J. Kennedy, O. A. Chadwick, P. M. Vitousek [et al.] // Geology. 1998. - Vol. 26. - . 1015-1018.

11. Kurtz A. C. Refractory element mobility in volcanic soils / A. C. Kurtz, L. A. Derry, O. A. Chadwick, M. J. Alfano // Geology. - 2000. - N 28. - P. 683-686.

12. Rabenhorst M. C. The chrono-continuum: An approach to modeling pedogenesis in marsh soils along transgressive coastlines / M. C. Rabenhorst // Soil Science. - 1997. N 162. - . 2-9.

13. Retallack G. J. Soils and Global Change in the Carbon Cycle over Geological Time / G. J. Retallack // Treatise On Geochemistry. - 2003. - P. 581-605.

14. Toshiyuki W. The rate of weathering and soil formation / Wakatsuki Toshiyuki, Rasyidin Azwar // Geoderma. - 1992. - Vol. 52. - Is. 3-4. - P. 251-263. 


\title{
CHANGES IN GEOCHEMICAL INDICATORS OF MODERN SOIL FORMATION IN CRIMEA
}

\author{
Olena Yergina \\ Taurida National V. I. Vernadsky University, \\ Academician Vernadsky Ave., 4, UA - 95007 Simferopol, Ukraine, \\ e-mail:YazcivLena@ramber.ru
}

In the article calculated and analyzed geochemical indicators that can be used to study the genesis and evolution of soils. The features of the changes in the coefficient eluviation, geochemical factors CIW and CIA, the coefficients of soil salinity of different ages in time, which were formed in the present conditions in Heracleian Peninsula, are studied.

Key words: geochemical factors, chronosequence, lithogeochemical indices, the coefficients of weathering.

\section{лен ргин}

врический н цион льный университет им. . . ерн дского, просп. к демик ерн дского, 4,95007, г. имферополь, кр ин e-mail: YazcivLena@rambler.ru

ссчит но и про н лизиров но геохимические пок з тели, которые можно использов ть для изучения генезис и эволюции почв. сследов но особенности изменения коэффициент элювииров ния, геохимических коэффициентов CIW и CIA, коэффициентов з соленности p зновозр стных почв во времени, которые сформиров лись в современных условиях почвообр зов ния н территории ер клейского полуостров

лючевые слов : геохимические коэффициенты, р зновозр стные почвы, литохимические индексы, коэффициенты выветрив ния. 